\title{
references
}

Casella, E.C. (2005) 'Prisoner of his majesty: postcoloniality and the archaeology of British penal transportation' World Archaeology Vol. 37, No. 3: 453-466.

Casella, $\boldsymbol{\varepsilon}$.C. and Fredericksen, C. (2004) 'Legacy of the fatal shore: the heritage and archaeology of confinement in post-colonial Australia' Journal of Social Archaeology Vol. 4, No. 1: 99-125.

Cremin, A. (2001) 1901, Australian Life at Federation, Sydney: New South Wales University Press.

Karskens, G. (1999) Inside the Rocks: The Archaeology of a Neighbourhood, Sydney: Hale and Iremonger.

Lavelle, S. (2003) 'A tree and a legend: the making of past and place in the Blue Mountains, NSW' Journal of the Royal Australian Historical Society Vol. 89, No. 1: 1-25.

Lydon, J. and Ireland, T. (2005) Object Lessons: Archaeology and Heritage in Australia, Melbourne: Australian Scholarly Publishing.

Mauss, M. (1950) Cunnison, I., translator, The Gift, London: Cohen \& West.

doi: $10.1057 /$ palgrave.fr. 9400346

\section{High culture: reflections on addiction and modernity}

Anna Alexander and Mark S. Roberts (editors); State University of New York Press, Albany, 2002, 4l6p, ISBN 0-7914-5554-8£14.00 (Pbk); ISBN 0-7914$5553-\mathrm{X} £ 48.00$ (Hbk)

High Culture moves drug use and addiction from the margins of culture and the confines of the clinic to the very centre of literary, artistic and philosophical discourse. By exploring the role of addictive desire in the production of modernity, this collection of essays makes an original and scholarly contribution to the growing field of critical and cultural studies of addiction.

The editors state that the book was 'conceived in a mode of "high" philosophical and ethico-political experimentation' (p. xi) and certainly readers will not find simple models of addiction or solutions to drug problems within its pages. The volume is refreshingly free from the pathologizing and therapeutic impulse. Instead, it connects addiction to 'fundamental questions about subjectivity, ontology, and desire, as well as political/ideological issues of representation, identification, and control' (p. xi).

The collection contains 17 chapters, many based on papers presented at a conference on Addiction and Culture held in Claremont, California in 1996. Another volume of essays, High Anxieties: Cultural Studies in Addiction, edited by Janet Farrell Brodie and Marc Redfield, also originated in this landmark conference and was published in 2002 (the author has an essay in this volume).

The first section of High Culture 'Philosophical and Literary Reflections on Addiction' contains essays on Nietzsche and the Dionysian high; Benjamin's hashish writings (and his writing addiction); Schelling and Heidegger; Burroughs 
and Levinas and Baudelaire and Artaud. It begins appropriately with a reprint of Derrida's 'On the Rhetoric of Drugs', an extensive and genuinely virtuoso discussion of the relationship between drugs, language, truth and pleasure. This interview contains some classic Derridean insights, my favourite is 'We do not object to the drug user's pleasure per se, but we cannot abide the fact that his or hers is a pleasure taken in an experience without truth' (p. 26).

For readers of Feminist Review, the essay by Elissa Marder, 'Trauma, Addiction and Temporal Bulimia in Madame Bovary' may well be the most engaging in this section as it connects with recent feminist explorations of modernity and femininity. It is also a pleasure to read. Beginning with a brief and elegant discussion of the temporal elements of trauma and addiction, Marder argues eloquently that Emma Bovary suffers from 'the quintessential malady of modernity, the inability to incorporate time into experience' (p. 133). Emma's disorder, marked by boredom, passivity and narcissism, is clearly connected to feminine subjectivity, female embodiment and the constraints of 19th century female existence. But according to Marder, Emma also 'incarnates and inaugurates' modernity, and in particular the forms of addiction and trauma that flourish in the contemporary West (p. 134). Like so many troubled modern subjects she is unable to live in the present, but cannot project a future and is 'subject to bouts of involuntary forgetting even as she is preoccupied by obsessive rites of recollection...' (p. 134).

The second section of the book 'Socio-cultural and Psychological Reflections on Addiction' is less coherent than the first, perhaps because the theme of modernity and the style of philosophical experimentation are not sustained. The essays range from Anna Alexander's fascinating account of Freud's cocaine writings to prominent rational choice theorist Jon Elster's analysis of compulsive gambling. It is difficult to understand why Elster's essay is included as its perspective and concerns are markedly different from the collection's overall approach (as evidenced by his confident assertion that neurophysiological research will answer the question of whether gambling is an addiction (p. 331)).

The only essay in this section which locates gender at the centre of its concerns, 'Smokescreen: The Cultural Meaning of Women's Smoking' also seems out of place in the book. Author Lorraine Greaves draws on rather dated feminist sources and ends with a surprising invocation of identity grounded in 'pure, clear, unmediated experience' (p. 275). Greaves has done important research on women and smoking, but this essay attempts to cover too much, resulting in a disappointingly superficial overview.

However, there are three essays in this section of the collection which deserve special mention. A useful companion to Derrida's interview, although in a more explicitly social-political mode is Felix Guattari's 'Socially Significant Drugs' which I have not seen in translation before. In this piece, Guattari argues for a 
broad decriminalization of hard drugs. Alphonso Lingis's 'Love Junkies' is a moving dialogue featuring long-term prisoners and addicts Cheryl and Wayne, whose relationship is exemplary and extraordinary despite its physical restrictions (although I was surprised to see the editors' introduction carelessly refer to Wayne's 'full blown AIDS' (p. 12)). Finally, John Fitzgerald's examination of the 'scopic technologies' utilized by public health in its efforts to monitor drug users, and the elusiveness of 'hidden populations' such as dance party Ravers is a brilliant example of Foucauldian analysis. Its nuanced account of the 'circular sleight of hand between scientific visibility and invisibility' has implications well beyond the essay's particular focus (p. 357).

Overall, this is an innovative and rewarding collection, which reveals the sometimes surprising intimacies between addiction and art, literature and philosophy.

doi:10.1057/palgrave.fr. 9400347

Helen Keane

\section{Nationalism and gender}

Chizuko Ueno (translated by Beverley Yamamoto); Trans Pacific Press, Melbourne, 2004, 263p, ISBN 1-8768-4353-5, £19.99 (Pbk), ISBN 1-87684359-4, £48.00 ( Hbk)

As Ueno says in the Epilogue, this book is about 'History'. 'History', however, not in a sense of events that happened in the past, but as an actual construction of the past, which is a project in progress and at the same time extremely political.

The existence of 'Military Comfort Women' who were systematically raped by the Imperial Japanese Military during the Second World War became widely known about after these women started to testify to their ordeals in the 1990s. The issue has particularly attracted the attention of feminists, who regard the 'Military Comfort Women' system as one of the worst examples of sexual violence against women. In addition, it has stirred up the interests of those concerned with Japanese war responsibility and reparation affairs. This has resulted in the emergence of various historical and political debates and movements, two of which are most significant. One of the movements is that of feminist and leftist historians who endeavour to reflect and re-write history through these women's testimonies. The other is the revisionist movement which refutes the validity of these women's testimonies.

As the translator of the book Yamamoto suggests Ueno has been frustrated by the fact that the debates around this issue have often been confined to the positivist 